\title{
DARIO FO: ZRODENIE KLAUNA
}

\section{MICHAL DENCI}

Divadelná fakulta Vysokej školy múzických umení, Bratislava

Abstrakt: Štúdia mapuje tvorbu talianskeho performera, držitel’a Nobelovej ceny za literatúru Daria Foa. Bázu predstavuje krátka rekapitulácia najsignifikantnejších epizód Foovej ranej kariéry. Biografická kapitola zahŕňa komikove prvé kontakty s profesionálnym divadlom, skúsenost' s filmom, televíziou a vznik prvých divadelných asociácií. Načrtnuté sú aj základné ideové východiská, ktoré podmienili formu i obsah Foovho divadla. Dramatická tvorba Daria Foa je analyzovaná prostredníctvom dvoch titulov, ktoré reprezentujú hlavné línie jeho produkcie. Prvú líniu tvoria klauniády, v rámci ktorých zaujímajú najvýznamnejšie miesto Mistero Buffo. Prevažne monologické formy inšpirované ludovým divadlom charakterizuje najmä jazyk grammelot a dôraz na pohybové a hlasové schopnosti performera. V druhej línii sa pozornost’ autora štúdie sústred'uje na groteskné komédie, zastúpené fraškou Morte accidentale di un anarchico. Hra inšpirovaná skutočnou udalostou reagovala na aktuálny spoločenský kontext a stimulovala spoločenskú diskusiu. Analýza genézy oboch diel zároveň odhaluje tvorivé postupy Daria Foa.

Klúčové slová: Dario Fo, politické divadlo, klauniáda, grammelot

Dario Fo (24. 3. 1926, San Giano - 13. 10. 2016, Miláno) sa nepochybne radí k najvýraznejším postavám svetovej divadelnej scény. Jeho aktivity neušli ani pozornosti Švédskej královskej akadémie vied, ktorá mu v roku 1997 prisúdila Nobelovu cenu za literatúru. V reakciách na udelenie tejto prestížnej ceny Fo často zdôrazňoval, že akadémia svojím gestom ocenila všetkých šašov histórie. Sám seba totiž považoval predovšetkým za predstavitel’a tejto špecifickej skupiny divadelných tvorcov. V najbližších kapitolách sa pokúsime v základných kontúrach načrtnút zrodenie azda najslávnejšieho talianskeho šaša 20. storočia.

\section{Od l'udových rozprávačov $\mathrm{k}$ l’avicovým intelektuálom}

Dario Fo strávil detstvo na lombardskom vidieku, tu odmalička s oblubou počúval príbehy l’udových rozprávačov. Po peripetiách 2 . svetovej vojny sa však rozhodol zúročit svoj maliarsky talent a zapísal sa na milánsku akadémiu umení Brera a na inštitút Politecnico, kde sa prihlásil na štúdium architektúry. V prostredí vel'komesta sa ako študent celkom prirodzene ocitol v kruhu intelektuálov vyznávajúcich lavicové myšlienky. V Taliansku položil základy tejto ideológie Antonio Gramsci, marxista uväznený počas vojny fašistami, ktorého zápisky z väzenia sa po vojne velmi rýchlo rozšírili v radoch inteligencie. Dario Fo sa $s$ jeho ideami nepochybne stretol. Aj teatrológ a Foov blízky priatel' Joseph Farrell vo svojej rozsiahlej biografii správne 
poznamenáva, že „akýkol’vek pokus o zhrnutie podstaty divadelnej poetiky Daria Foa sa musí začat' Gramscim, ktorý dôraz marxistickej teórie presunul z ekonómie na kultúrne aspekty “1.

Antonio Gramsci prisudzoval dôležitost' l’udovému umeniu, ktoré vnímal ako prejav spontánnej filozofie l’udu. Snažil sa tak vyvrátił’ domnienku, že filozofia ako intelektuálna aktivita je vlastná len úzkej skupine vedcov či profesionálnych filozofov. Zároveň tvrdil, že $\mathrm{v}$ každom spoločenstve l'udí existuje usporiadanie, $\mathrm{v}$ rámci ktorého možno identifikovat’ vrstvu intelektuálov, čiže tých, ktorí sa špecializujú na konceptuálne spracovávanie a na filozofiu samotnú, a potom vrstvu tých, ktorí filozofiu uvádzajú do praxe prostredníctvom „zdravého sedliackeho rozumu“. Za dôležité považoval, aby sa v spoločnosti udržiaval kontakt medzi elitou a "prostým“ ludom. Absencia komunikácie medzi intelektuálmi a väčšinovým obyvatel’stvom či nedostatočná stimulácia progresu prostých ludí mali za následok vzájomné odcudzenie týchto dvoch skupín. Prostý lud nebol viac schopný porozumiet elite, preto ju prestal rešpektovat'. Obzvlášt v demokratickom systéme, kde rozhoduje názor väčšiny, mal takýto vývoj často nepriaznivý dopad na celé spoločenstvo. Napredovanie izolovanej skupiny intelektuálov sa tak v kontexte spoločnosti ukazovalo ako celkom zbytočné. Každému pokroku vrstvy intelektuálov by v ideálnom prípade mal zodpovedat' analogický pokrok más, ktoré ich budú nasledovat'. Jedným zo spôsobov na dosiahnutie tohto progresu by malo byt’ zavedenie kritického myslenia u masového človeka, ktorý je aj s pomocou kultúry stimulovaný k tomu, aby podrobil kritickej analýze svoju filozofiu, čiže svoj „zdravý sedliacky rozum“. ${ }^{2}$

\section{Prvé kontakty s divadlom}

Dario Fo v snahe priblížit’ sa k profesionálnemu divadlu vyhl'adal v Miláne komického herca Franca Parentiho, ktorého poznal zo Strehlerovho Piccolo teatro ${ }^{3}$. Prezentoval mu niekol'ko návrhov scénografií a zmienil sa aj o svojej vášni pre komické divadlo. Parenti poskytol mladému Foovi priestor na prezentáciu v rámci jedného zo svojich kabaretných predstavení a na základe tejto skúsenosti ho hned' prijal do svojej divadelnej skupiny. Skupina Franca Parentiho priniesla Foovi najdôležitejšie stretnutie v jeho súkromnom i umeleckom živote. Práve v tomto súbore totiž spoznal budúcu manželku, herečku Francu Rame. Jej prínos do tvorby Daria Foa je mimoriadne vel'ký, Foovo pôsobenie je preto potrebné vnímat' v spojitosti s Rameovej výnimočnou osobnostou. Franca Rame sa narodila do divadelnej rodiny s niekol'kogeneračnou tradíciou. Divadelníctvo sa tu dedilo z pokolenia na pokolenie, a tak jej bol od počiatku predurčený osud herečky. Foovi sprostredkovala autentickú divadelnú tradíciu, ktorú by inak pravdepodobne nemal odkial čerpat'. Ako skúsená divadelníčka mu zároveň pomáhala dramaturgickými pripomienkami a usmerňovala jeho prejav.

${ }^{1}$ FARRELL, Joseph. 2014. Dario e Franca. La biografia della coppia Fo-Rame attraverso la storia italiana, verzia e-book: Ledizioni. EAN: 9788867051526, s. 14. Preklad z talianskeho jazyka Michal Denci.

${ }^{2}$ Je nutné poznamenat', že uvedený výklad je vel’mi zjednodušený a má slúžit’ skôr ako ilustrácia myšlienok, ktoré ovplyvnili Foa v jeho tvorbe, než ako vyčerpávajúca explikácia vel’mi komplexných Gramsciho teórií.

${ }^{3}$ Piccolo teatro di Milano, založené v roku 1947 Paolom Grassim, jeho manželkou Ninou Grassi a Giorgiom Strehlerom, si najmä vd’aka Strehlerovým réžiám v priebehu 20. storočia vydobylo status jednej z najuznávanejších divadelných inštitúcií v Taliansku. 
$\mathrm{Aj}$ preto sa v textoch, ktoré takmer výlučne zapísala a spracovala Franca, autorstvo spravodlivo prisudzuje dvojici Fo - Rame.

Hereckému umeniu sa Fo začal na profesionálnej úrovni priúčat v Parentiho súbore. V tomto období boli pre neho obzvlášt’ obohacujúcimi najmä stretnutia s Giorgiom Strehlerom a tiež s Jacquesom Lecoqom, ktorý mu pomohol zdokonalit’ pohybový prejav. Prínos oboch velikánov pre kvalitu Foovho divadelného prejavu bol mimoriadne citelný. Foov razantný nástup na divadelnú scénu však nekompromisne zabrzdila cenzúra. Jeho prvé diela Il dito nell'occhio (Prst v oku) či I sani da legare (Zdraví, ktorým treba dat' kazajku) padli za obet’ cenzorom. V divadelnej skupine sa zároveň objavili nezhody prameniace z odlišných záujmov jeho jednotlivých komponentov. Parenti inklinoval skôr k avantgardným autorom (napr. Ionescovi), čo nevyhovovalo Foovi, ktorý pri formovaní svojho divadelného jazyka vychádzal najmä z tradície l'udových rozprávačov. Rozpad súboru vysvetloval Parenti aj Foovým záujmom o nové médium: film.

S ambíciou presadit sa vo svete kinematografie sa Dario s Francou prestahovali do Ríma. Fo veril, že tu nájde uplatnenie ako scenárista, aj ako herec. Film s názvom Lo svitato (Vykrútený), ktorý vznikol na základe niekol'kokrát upraveného Foovho scenára, však zaznamenal neúspech. Foova skúsenost’ s kinematografiou tak nemala dlhé trvanie, no v konečnom dôsledku sa ukázala ako vel'mi podnetná: práve vd’aka práci vo filmových štúdiách mohol komik rozvinút’ schopnost’ syntetizovat’ akciu a vnímat’ obraz vo viacerých rovinách. Fo a Rame sa po tejto skúsenosti rozhodli vrátit’ opät' k divadlu, ktoré vnímali ako bezprostrednejší prostriedok na komunikáciu s publikom. V Miláne dostali k dispozícii priestor Piccolo teatro, kde s úspechom hrali Foove frašky. Dario pri ich písaní vo vel'kej miere zúročil materiál, ktorý získal od Frankinej rodiny.

Prvá rozsiahlejšia Foova komédia s názvom Gli arcangeli non giocano a flipper (Archanjeli nehrajú flipper ${ }^{4}$ z roku 1958 inaugurovala tzv. buržoázne obdobie ${ }^{5}$ jeho divadelníckej kariéry. Prívlastok „buržoázne“, ktorý používa Farrell na definíciu Foovho pôsobenia v rokoch 1958 - 1968, však nijako nesúvisí s obsahovou stránkou komédií. Vyplýva výlučne zo skutočnosti, že ich Fo hrával prevažne v buržoáznych (meštianskych) divadelných inštitúciách. Texty z tohto obdobia (tak ako väčšinu jeho textov) charakterizuje pomerne vel'ká premenlivost'. Fo si repliky často prispôsoboval, reagujúc na momentálnu spoločenskú a politickú situáciu, vd’aka čomu publiku vždy ponúkal úderné a aktuálne predstavenia. Do Foovho buržoázneho obdobia radíme jednotlivé dramatické texty najmä na základe dátumu ich vzniku a na základe skutočnosti, že z formálneho hladiska išlo v podstate o klasické komédie. Popri Gli arcangeli non giocano a flipper sem patria napríklad tituly Aveva due pistole con gli occhi bianchi e neri (Mal dve pištole s čiernymi a bielymi očami, 1960) či Chi ruba un piede è fortunato in amore (Kto ukradne nohu, má štastie v láske, 1961). Niektoré z nich zaznamenali ohlas i v zahraničí a priniesli Foovi medzinárodné uznanie. V Taliansku boli Dario Fo a Franca Rame v tom čase už pomerne známymi osobnost’ami s jasne čitatel’ným umeleckým profilom a politickým postojom. Prav-

\footnotetext{
${ }^{4}$ Komédiu do slovenčiny preložil Blahoslav Hečko v roku 1963 pod názvom Archanjeli nehrajú biliard. Fo však v názve zámerne uviedol hru flipper, ktorá pohoršovala konzervatívnu spoločnost’ a pri ktorej sám rád trávil čas. $S$ ohl'adom na túto skutočnost’ je v tejto štúdii v názve komédie zachovaná hra flipper.

${ }^{5}$ Označenie používa Joseph Farrell v citovanej Foovej biografii.
} 
depodobne aj z toho dôvodu si ich prizvali k spolupráci l’avicoví zástupcovia vo vedení televízie RAI.

\section{Prípad Canzonissima}

Na konci roku 1961 vznikol druhý kanál televíznej spoločnosti RAI ako skúšobné laboratórium, ktoré malo slúžit’ na testovanie rôznych televíznych produkcií. Dario Fo prijal ponuku na účinkovanie a s programom Chi l'ha visto (Kto to videl), v ktorom parodoval rôzne iné televízne šou, sa tešil vel'kej oblube publika. Jeho neprehliadnutelný úspech motivoval vedenie televízie RAI, aby Foovi vytvorilo priestor v rámci vysielania prvého kanálu. Program Canzonissima (Šlágrovica), ktorý mu televízni producenti zverili, mal podla pôvodných zámerov len spestrovat žrebovanie národnej lotérie. Čoskoro sa však stal jedným z najväčších t’ahákov hlavného vysielacieho času. Pozornost’ divákov prit’ahovali najmä satirické skeče, prostredníctvom ktorých Fo kritizoval aktuálne politické pomery. Ako rozhodujúce sa pre Foa ukázalo jeho účinkovanie $\mathrm{v}$ jedenástom pokračovaní, kde sa komik chystal nastolit’ otázku bezpečnosti pracovníkov v stavebnom priemysle. Po tom, čo mu televízia neumožnila v programe vystúpit', zrodila sa jedna z najväčších mediálnych káuz v Taliansku, ktorá Foovi zaručila vel'kú popularitu obzvlášt v radoch robotníkov.

\section{Divadlo pracujúcej triedy}

Aj vzhl'adom na svoju politickú profiláciu sa Dario Fo na konci šest’desiatych rokov často stretával s neochotou prevádzkovatel'ov divadelných priestorov. Tradičné divadelné stánky sa navyše javili ako nevhodné pre jeho vystúpenia nielen z pohladu prenajímatel'ov, ktorí preferovali konformnejšie produkcie, ale i z pohl'adu divákov. Dario Fo a Franca Rame si uvedomili, že v meštianskych divadlách navštevovaných prevažne príslušníkmi buržoázie sa len sporadicky prihovárajú robotníckej triede, ktorej boli adresované ich diela. V snahe zosúladit právnu formu súboru s proklamovanými myšlienkami teda založili asociáciu Nuova Scena. Po dohode s predstavitel'mi $\mathrm{ARCI}^{6}$ začala asociácia uvádzat’ svoje komédie v tzv. l’udových domoch. Nových divákov mali v úmysle oslovit divadelným útvarom, ktorý Dario Fo definoval ako totálne divadlo: herci používali v predstaveniach vel'korozmerné bábky, prostredníctvom ktorých sugestívne ilustrovali nespravodlivé pomery v spoločnosti. Nápad dvojice Fo - Rame evidentne fungoval. Podla údajov, ktoré zverejnilo príslušné ministerstvo, v prvej sezóne navštívilo ich predstavenia v l’udových domoch okolo 240 tisíc divákov, pričom pre $90 \% \mathrm{z}$ nich to bola podl'a ich vlastných slov prvá skúsenost' s divadlom.

Ušlachtilé ideály demokratického spravovania divadelnej skupiny sa však časom ukázali ako nekompatibilné s Foovou osobnostou. Svojím talentom a schopnostami vysoko vyčnieval nad ostatnými, preto ho často brzdila nutnost’ prijímat' všetky rozhodnutia konsenzuálne. Na to, aby sa mohol plne umelecky prejavit', potreboval vo svojom divadle zaujat pozíciu despotu. Po skúsenosti s asociáciami Nuova Scena a La Comune, ktorá prvý menovaný subjekt po jeho zániku nahradila, si Dario Fo a Franca Rame opät’ zvolili cestu klasického divadelného súboru.

\footnotetext{
${ }^{6}$ Associazione Ricreativa e Culturale Italiana. Asociácia bola založená v roku 1957 vo Florencii ako federácia lavicovo orientovaných združení.
} 


\section{Dve línie}

Teatrologička Anna Barsotti identifikuje v tvorbe Daria Foa dve základné línie: jednu z nich predstavujú klauniády, druhú groteskné komédie. Obe línie sa vyvíjali paralelne, čo dokazuje aj skutočnost', že diela, ktoré Barsotti v súvislosti s týmito líniami označuje za vrcholné, vznikli v rokoch 1969 a 1970. Barsottiovej štúdia bola publikovaná v roku 2007, teda v čase, ked’ bol Dario Fo stále produktívny a jeho tvorba ešte nebola zavŕšená. Napriek tomu sa s jej názorom možno stotožnit: dnes sa už dá konštatovat', že práve ňou citované diela sa zrejme najvýraznejšie zapísali do dejín talianskej drámy. Z tohto dôvodu pristúpime ku krátkej analýze jednotlivých línií prostredníctvom dvoch reprezentatívnych dramatických textov, Mistero buffo a Morte accidentale di un anarchico.

\section{Klaunské mystériá}

Kontakt s hudobnou skupinou Nuovo canzoniere italiano ${ }^{7}$, s ktorou v polovici šest'desiatych rokov spolupracoval na tvorbe programu s názvom Ci ragiono e canto (Zamyslím sa nad tým a spievam), podnietil Daria Foa k dôslednému štúdiu l'udovej kultúry. Poznatky, ktoré v tom období nadobudol, neskôr zúročil pri tvorbe svojho azda svetovo najznámejšieho diela, Mistero Buffo. Prekladatel' Blahoslav Hečko preložil tento titul do slovenčiny ako Buffonáda zázrakov. Krátka genéza názvu, ktorú podáva Dario Fo, však naznačuje, že je vhodnejšie zachovat’ v názve pojem „mystérium“. Tento termín podla Foa používali starovekí Gréci na označenie ezoterických kultov, ktoré tvorili základ pre vznik performatívnych foriem znázorňujúcich činy bohov. Neskôr ho prevzali krest’ania, ktorí ním pomenúvali hry, resp. scénické obrazy, prostredníctvom ktorých ilustrovali príbehy svätých. Prívlastok „klaunské“ , ktorý Fo pripojil k mystériám, indikuje, že v jeho podaní sú tieto príbehy interpretované groteskne a satiricky. Preto aj v tejto štúdii používame názov Klaunské mystériá. ${ }^{8}$

Z hladiska formy možno Klaunské mystériá definovat’ ako sériu monológov, ktoré sú uvádzané vysvetl'ujúcimi predslovmi. Niektoré z mystérií sú v knižnej edícii spracované tiež v dialógoch, čo umožňuje ich interpretáciu viacerými hercami, všetky mystériá však majú aj monologickú verziu. Zaradenie úvodov pred mystériá zrejme do istej miery podnietil Foov obdiv k renesančnému hercovi Ruzzantemu, ktorý svoje scénky tiež uvádzal krátkym predslovom. Špecifikom predslovov Daria Foa bola snaha uviest’ publikum do problematiky hry prostredníctvom ozrejmenia jej historického a kultúrno-spoločenského kontextu s dobou. Zároveň v nich nezriedka komentoval aktuálne politické dianie, z čoho vyplýva, že jednotlivé predslovy podliehali vel'kej variabilite. Predslovy vo Foovom prípade zohrávali pomerne dôležitú úlohu pri ozrejmení situácie, ktorú sa chystal stvárnit'. Vd’aka uvedeniu do deja dokázalo publikum bez problémov sledovat monológy v jazyku, ktorý je založený takmer výlučne na zvukovej expresivite.

\footnotetext{
${ }^{7}$ Skupina vznikla v roku 1962 v Miláne. Tvorili ju hudobníci a muzikológovia, ktorých cielom bolo prispiet’ k uchovaniu tradičných l’udových piesní talianskych regiónov. Vo svojom výskume sa zameriavali na piesne, ktoré boli vyjadrením odboja l'udu voči autoritám.

${ }^{8}$ Vzhl'adom na to, že nejde o názov, ktorý by bol kodifikovaný oficiálnym vydaným prekladom, uvádzame ho bez kurzívy.
} 
Foov divadelný jazyk pritiahol pozornost’ viacerých teatrológov, divadelných kritikov či lexikológov. Franca Rame spomína Gianfranca Folemu, ktorý sa venoval štúdiu stredovekých jazykov a ktorého definíciu cituje aj vo svojej autobiografii: „Táto divadelná interlingua je $\mathrm{v}$ podstate individuálnym nadgramatickým jazykom, ktorý však má pri orálnom podaní silnú komunikačnú schopnost'. Na to, aby bol pochopený, od publika nevyžaduje žiadne špeciálne znalosti nárečia, pretože mimika, lazzo ${ }^{9}$, onomatopoje kompenzujú zdanlivú jazykovú lubovôlu a sémantické nedostatky, a tiež preto, lebo Fo ako vel'ký mím majstrovsky ovláda techniku prejavu a l'udového rozprávačstva. ${ }^{\prime 10}$

Folemova definícia je vskutku vel’mi presná a komplexná. V úvode citovanej časti hovorí o interlingue, teda o umelom jazyku vol’ne založenom na latinčine. Tento jazyk charakterizuje ako individuálny, čo znamená, že ho de facto spája s osobou Daria Foa. Ďalej menuje prvky, s pomocou ktorých dosahuje mím Fo jeho expresivitu. Zahŕňa sem prevažne prostriedky neverbálnej komunikácie, ako sú mimika tváre či pohyb tela. V inej časti štúdie Folema opät’ výstižne konštatuje, že bez takýchto neverbálnych prostriedkov funguje Foov jazyk len ako „mnémonická stopa alebo verbálne canovaccio“ ${ }^{\prime 1}$.

Foov grammelot je teda výsostne divadelný jazyk, ktorý sa v písomnej podobe bude vždy javit’ ako neúplný. Bolo by zbytočné hladat’ v ňom akúkol’vek literárnu kvalitu. Dario Fo počas rôznych seminárov či laboratórií, ktoré sú spracované aj v publikácii Manuale minimo dell'attore, vysvetlil niektoré základné princípy, ktoré uplatňoval pri tvorbe svojho divadelného jazyka: „Na prerozprávanie príbehu v grammelote je potrebné mat' istú zásobu zvukových a tónových stereotypov, ktoré sú najcharakteristickejšie pre daný jazyk, a dobre poznat' rytmus a kadencie jazyka, ktorý má byt' evokovaný. (...) Ktoré klúčové body musíme mat' na pamäti, aby sme zrealizovali grammelot? Predovšetkým musíme informovat publikum o téme, ktorú budeme interpretovat' (...) K tomu je potrebné pridat' klúčové prvky, ktoré prostredníctvom gest a zvukov určujú špecifické charaktery (...). Je zrejmé, že nemôžem prerozprávat' kompletné dialógy, ale ich len naznačit', načrtnút'. (...) Zrekapitulujem to: onomatopoické zvuky, čistá a evidentná gestikulácia, odtiene, rytmy, koordinácia a najmä vel'ká syntéza. “12

Ako sme už naznačili pri zmienke o jeho relatívne krátkom pobyte v Ríme, Fo si osvojil schopnost’ syntetizovat príbeh vd’aka práci vo filmových štúdiách. Kontakt s kinematografiou mu však otvoril aj mnohé d’alšie obzory a ovplyvnil jeho nazeranie na divadlo. Dario Fo tvrdil, že každý divadelný divák má v hlave kameru, cez ktorú nazerá na predstavenie odohrávajúce sa pred jeho očami. Toto uvedomenie mu dovol’ovalo kontrolovat' koncentráciu diváka. Ked' potreboval, aby sa publikum zameralo na jeho mimiku, zámerne znehybnil celý zvyšok tela, aby pozornost’ presunul na tvár. A naopak, ked' chcel dosiahnut, aby divák vnímal scénu ako celok, do pohybu zapojil celé telo. Po citovanej explikácii nasledovala krátka ukážka, ktorú Fo vzápätí

\footnotetext{
${ }^{9}$ Komická akcia, skeč typický pre komédiu dell'arte.

${ }^{10}$ Cit. podla Fo, Dario - RAME, Franca. Una vita all'improvvisa. Milano : Ugo Guanda Editore, 2009, s. 220. ISBN 978-88-6088-597-5. Preklad z talianskeho jazyka Michal Denci.

${ }^{11}$ Tamže, s. 218. Canovaccio je scenár používaný v komédii dell'arte. V tomto scenári nie sú zapísané konkrétne repliky, ale len sled situácií.

${ }^{12}$ FO, Dario. Manuale minimo dell'attore. Torino : Einaudi, 1997, s. 82. ISBN 978-88-06-20051-0. Preklad z talianskeho jazyka Michal Denci.
} 
okomentoval: „Miestami počas monológu som sa sústredil na to, aby som doň zaradil l’ahko zrozumitel’né termíny, kvôli logickému pochopeniu počutého textu. (...) Zároveň som s pomocou gest určil (...) termíny, ktoré som komolil v napodobenine južanského dialektu, no ktoré sa nikdy neobjavovali náhodne. Vskutku základným momentom tohto drmolenia je prepojenie so správnym a špecifickým slovom, ktoré spolu určíme." ${ }^{13}$

Komik si teda vyčlení klúčové pojmy a priradí im špecifické monémy. Vytvára tak nový jazyk, pričom v závislosti od zvoleného dialektu, ktorý má byt’ evokovaný, pracuje s konkrétnymi zvukovými charakteristikami.

\section{Pohl'ad do Biblie i mimo nej}

Korpus Klaunských mystérií sa postupom času menil a stále narastal. Uchopił Klaunské mystériá ako celistvé dielo je preto vel'mi tažké. Pri tejto snahe sa môže stat' nápomocným rozdelenie mystérií do skupín na základe ich súvisu s Bibliou.

$\mathrm{Z}$ tohto hladiska predstavujú ústrednú skupinu príbehy priamo súvisiace s výjavmi z Biblie alebo tie, ktoré sú inšpirované apokryfnými evanjeliami. Patria sem napríklad mystériá ako Vraždenie neviniatok, Zázrak zo svadby v Káne, Vzkriesenie Lazara či Prvý zázrak diet’ata Ježiša. Nie všetky tieto tituly sú komické: zvlášṫ mystériá, ktoré interpretovala Franca Rame (napr. Stretnutie Madony s Máriami, Mária pri kríži), možno definovat’ ako vyslovene tragické. V súvislosti s tými mystériami, ktoré obsahujú prvky komiky, treba poznamenat', že Fo nikdy nedehonestuje samotné biblické postavy. Ich činy ale zasadzuje do kontextu všedného sveta reálnych l'udí so všetkými ich malichernostami. Z príbehov tak nevyžaruje mystickost', ale skôr humánnost' protagonistov, resp. ludskost' (v pozitívnom a niekedy i v negatívnom zmysle) interpretovaných postáv.

Druhú skupinu tvoria mystériá popisujúce dobové reálie s presahom do súčasnosti. Medzi najznámejšie tituly z „nebiblickej“ sekcie patria Anglický advokát či Zanniho hlad. Príbehy často vykresl'ujú spoločenskú nespravodlivost', ktorá v rôznych formách pretrváva do súčasných dní.

Niektoré mystériá sa nachádzajú na pomedzí: objavujú sa v nich aj biblické postavy, no vystupujú skôr ako komparz či vedlajšie postavy. Protagonistami sú l'udia, ktorí pri stretnutí so svätcami rôznymi spôsobmi prejavujú svoj nedokonalý ludský charakter. Do tejto kategórie možno zaradit napríklad tituly Bonifác VIII. alebo Zrodenie klauna.

Na ilustráciu mystérií zaradených do spomínaných kategórií nám poslúži krátky rozbor niektorých reprezentatívnych titulov.

\section{Zanniho hlad}

Hned' v prvej časti predslovu upozorňuje Dario Fo divákov, že túto epizódu - na rozdiel od väčšiny ostatných, ktorých pôvod siaha do stredoveku - prebral od renesančných komikov dell'arte. Otvára sa mu tak priestor na to, aby popísal aj vznik jazyku grammelot.

${ }^{13}$ Tamže. 
Autormi tohto univerzálneho jazyka boli podla neho práve renesanční komici, ktorých rekatolizačné hnutia donútili v druhej polovici 16. storočia opustit’ domovinu. V zahraničí museli títo komici nájst’ spôsob, ako komunikovat’ s publikom, a tak začali používat’ vysoko expresívny jazyk založený prevažne na onomatopojách. Najstarší grammelot prisudzuje Fo postave Zanniho, ktorého označuje za prototyp všetkých masiek komédie dell'arte.

Po úvode prechádza Fo rovno k samotnej klauniáde, ktorej ústredným motívom je hlad. Zanni si najprv predstavuje, že požiera sám seba, potom začne blúznit a nadobúda dojem, že sa nachádza v dobre zásobenej kuchyni, kde si pripravuje honosné jedlo, aby napokon $\mathrm{z}$ tohto stavu vytriezvel a uvedomil si, že išlo len o ilúziu. Klauniáda má „,štastný“ koniec: Zannimu pristane na nose mucha, ktorú po malých kúskoch s vel'kou chutou zje. Na videách zachytávajúcich túto klauniádu vo Foovom podaní možno vel'mi dobre pozorovat' komikovu prácu s telom a s mimikou tváre. Práve intenzívne zapojenie mimiky tváre vyznieva paradoxne vo svetle informácie, že Fo - ako sám deklaruje v úvode - sa pri koncipovaní tejto klauniády inšpiroval komikmi dell'arte. Jedným z charakteristických znakov postáv tejto divadelnej formy je totiž tvárová maska. Pokial' by ju Fo použil, nemohol by pasáž s muchou odohrat' takým spôsobom, aký je zaznamenaný aj na videách. Na túto skutočnost̉ upozornil Marco Consolini na konferencii s názvom „Divadlo ako hodnotový diskurz - slovenské divadlo a súčasná európska divadelná kultúra“", ktorá sa konala v roku 2017 v Bratislave. Potvrdzuje sa tak teória, že Foove mystériá netreba vnímat’ ako historickú rekonštrukciu, ale ako adaptáciu klaunských foriem na súčasnost'.

\section{Bonifác VIII.}

Mystérium, ktorého protagonistom je stredoveký pápež Bonifác VIII., sa radí k najkontroverznejším Foovým klauniádam. Dario Fo sa o pápežovi velmi nelichotivo vyjadruje už v úvode, ked’ ho vykresl'uje ako bezcitného hodnostára s mocenskými chútkami. Publiku sprostredkúva niekol'ko epizód z jeho života, ilustrujúcich pápežovu krutost’ a zvrátenost'. Väčšinou ide o príbehy masakrov, popráv či organizovania sexuálnych orgií. Súhrnne by sa dalo povedat', že Fo popisuje Bonifáca VIII. ako pápeža, ktorý na jednej strane oslobodil cirkev od politických vplyvov panovníkov, no na druhej strane prispel k jej premene na skutočnú svetskú mocnost'. Mnohé z ním popisovaných udalostí sa pritom nenachádzajú v knihách histórie, podla Foovho výkladu ide prevažne o orálne tradované anekdoty. Oficiálne dejiny totiž podl’a komika tvorili najmä ich hlavní aktéri, ktorí boli pri zaznamenávaní jednotlivých počinov pochopitelne selektívni a vyzdvihli predovšetkým hrdinské gestá, zatial čo menej slávne momenty zamlčali.

V prvej časti mystéria prebieha príprava pápeža na procesiu. S pomocou služobníkov sa oblieka do honosných šiat, kým intonuje gregoriánsky spev. Fo v úvode upozorňuje publikum, že v prípade tohto spevu nejde o grammelot, ale o autentický liturgický text. Skutočným majstrovstvom v tejto časti je Foovo znázornenie zboru: pápež kňazom najprv udáva tóniny, aby si potom pri spoločnom speve všimol, že jeden zo spevákov intonuje falošne. $V$ tomto obraze uplatňuje komik široké hlasové spektrum, vd’aka ktorému dokáže naraz interpretovat niekol'ko spievajúcich postáv.

Situácia dostane nový impulz, ked’ sa pápežova procesia stretne s inou. Cestu vrchnej cirkevnej autorite skríži sprievod, ktorý odprevádza Ježiša Krista na Golgo- 
tu. Bonifác VIII. zacíti príležitost’ ukázat’ sa pred očami l’udu pri samotnom Kristovi, rýchlo sa zbaví honosných šiat a snaží sa vtesnat' k Ježišovi pod kríž. Nazaretský v ňom ale nespoznáva svojho nasledovníka a nemá pre toto gesto pochopenie. Kopne Bonifáca do zadku, čím zároveň spečatí názov krížovej kosti. Urazený pápež sa znova oblečie a pokračuje v okázalej procesii.

Fo v svojej interpretácii mystéria pracuje vo vel'kej miere s pantomímou (pri obliekaní do šiat), využíva náznak (napr. pri znázorňovaní hompálajúcich sa mníchov visiacich na jazyku) aj hyperbolu (napr. pri kopanci do zadku). Asi najviac však vyniká jeho gregoriánsky spev, ktorý navodzuje atmosféru cirkevného prostredia.

\section{Vzkriesenie Lazara}

Mystérium, v ktorom Fo reinterpretuje biblický obraz vzkriesenia Lazara, zaujme diváka nielen $\mathrm{z}$ tematického, ale aj z formálneho hladiska. Ako Fo vysvetl'uje v úvode, ide o technicky pomerne náročný kúsok, ktorý si vyžaduje značnú mimickú a vokálnu obratnost', ked’že klaun musí interpretovat’ približne pätnást' postáv za sebou bez toho, aby naznačoval zmenu postavy inak než svojím telom: ani tak, že by menil hlas, ale len prostredníctvom póz.

Zázrak vzkriesenia je v mystériu znázornený cez optiku bežných ludí. Medzi približne tuctom postáv, ktoré Fo stelesňuje, tak nenájdeme nikoho z protagonistov: Ježiš, jeho nasledovníci aj Lazar sú zobrazení len prostredníctvom opisov či reakcií iných postáv. Franca Rame zaznamenala v prepise tejto klauniády postavy ako "návštevník", „strážca cintorína“, "d’alší návštevník“, „hlas z davu“, "prenajímatel' stoličiek" a podobne. Dario Fo najmä pomocou rýchlych zmien póz dokáže navodit’ dojem pomaly sa zväčšujúceho davu ludí, ktorí sa prišli pozriet na zázrak. Všetko to, čo sa na mieste deje, prispieva k zreálneniu situácie, ktorá v predstavách ludí väčšinou nesie známky mágie. Toto mystérium preto v istom ohlade funguje ako skúška krestanskej tolerancie. Zároveň však môže slúžit na preverenie hercových schopností, na niektorých umeleckých akadémiách sa totiž šikovnost’ študentov testuje práve na tomto divadelnom kúsku.

\section{Anglický advokát}

Mystérium o anglickom advokátovi zaradil Fo do časti, v ktorej prezentuje rôzne typy jazyka grammelot. Anglický grammelot podla neho patrí k tým najznámejším a najoblúbenejším od čias renesančných giullari ${ }^{14}$. Už oni totiž často prenášali dej kontroverzných príbehov za Lamanšský prieliv, aby sa vyhli hrozbe trestu za zosmiešňovanie vrchnosti, ktorá by sa v niektorých obrazoch mohla lahko spoznat'. Podobne to bolo aj v prípade anglického advokáta, ktorý obhajoval istého lorda obvineného zo znásilnenia.

Dario Fo spomína Fridricha II., aby demonštroval, že sexuálne zneužívanie bolo odjakživa súčastou ludského spoločenstva. Podla zákona vydaného týmto panovníkom bol zbavený viny každý previnilec z vyššej spoločenskej vrstvy, ktorý pri pristihnutí pri znásilnení zvolal „Nech žije imperátor, vd’aka Bohu!“ a na obet položil sumu

${ }^{14}$ Šašovia. Od toho slova je odvodené slovo "giullarata“, teda divadelná forma, s ktorou pracoval aj Fo. 
peňazí, nazývanú defensa (obrana). V mystériu je situácia iná. Lord pochádza z nižšej spoločenskej vrstvy než znásilnená žena, preto sa naň spomínaný zákon nevzt’ahuje. Šikovný obhajca však na jeho obranu použije argument, s ktorým sa nezriedka stretávame i dnes. Na vine všetkému nebol muž, ale nehanebná, vyzývavá žena. Lord, ktorý svoj čas bežne venuje sústredenému štúdiu diel klasikov a modlitbám, pri jej prehnane zvodnej ženskosti totiž nemal inú možnost', než sa na ňu vrhnút'. Tento model Dario Fo v úvode prepája so súčasnostou: v rozhovoroch bežných l’udí aj dnes často zaznieva absurdný názor, že istý podiel viny na znásilnení nesie samotná obet'. Vzhladom na to, že Fo interpretuje mystérium v anglickom grammelot, nenachádzame v knižnej edícii prepis textu, ale popis akcií. Dario Fo najprv znázorňuje cudného muža ponoreného do štúdia, aby potom pantomimicky a s použitím vel'kej pohybovej hyperboly vykreslil zmyselnú ženu, ktorej sa muž nakoniec musí chtiac-nechtiac zmocnit.

Téma znásilnenia sa bezprostredne dotkla aj života partnerskej dvojice Fo - Rame. Pravdepodobne pre jej angažovanie sa v boji za práva väzňov (v tom čase nezriedka nespravodlivo obvinených) sa Franca Rame stala obetou hrubého znásilnenia štyrmi mužmi. Smutná na celom prípade je popri inom skutočnost', že nemožno vylúčit priame zaangažovanie politických špičiek do objednávky tohto odsúdeniahodného skutku. Ba čo viac, mnohé indície tomu nasvedčujú. Politika však zasiahla do života dvojice aj v mnohých iných prípadoch, ked’že Fo a Rame sa intenzívne zapájali do politického diania v krajine.

\section{Náhodná smrt’ anarchistu}

Taliansko na prelome šest'desiatych a sedemdesiatych rokov minulého storočia poznačili bombové atentáty, ktoré si vyžiadali mnoho ludských obetí. Pri najtragickejšej z udalostí, explózii bomby v banke na Piazza Fontana v Miláne v decembri 1969, prišlo o život 17 l’udí a d’alších 88 bolo zranených. Z prípravy atentátu boli takmer ihned' obvinení predstavitelia anarchistických skupín, Pietro Valpreda a Giuseppe Pinelli. Oboch vypočúvala talianska polícia, Pinelli za dodnes nevyjasnených okolností prišiel počas výsluchu o život. Jeho telo bolo nájdené pred budovou prokuratúry. Podla oficiálnej verzie Pinelli sám vyskočil z okna na štvrtom poschodí. Správa, s ktorou bol archivovaný príslušný vyšetrovací spis, hovorí doslova o „náhodnej” Pinelliho smrti. Valpredovi a Pinellimu nikdy nedokázali podiel viny na organizácii útokov z námestia Fontana. V roku 2005 boli ako zodpovední za prípravu atentátov definitívne označení dvaja predstavitelia pravicovej militantnej skupiny Ordine Nuovo, Franco Freda a Giovanni Ventura. Dodnes nebol nikto obvinený z priamej realizácie atentátu.

Oficiálne vysvetlenie Pinelliho smrti už od počiatku obsahovalo množstvo nezrovnalostí. Za účelové možno označit samotné obvinenie zo zosnovania atentátu. Popis priebehu výsluchu a napokon jeho pádu z okna odporoval akejkolvek logike. Väčšina talianskej tlače komentovala prípad len vel'mi opatrne, Dario Fo spolu s členmi súboru sa preto rozhodli suplovat úlohu najväčších denníkov a vytvorit’ divadelné dielo, ktoré by spíňalo funkciu informačného žurnálu a zároveň spúštača širšej spoločenskej diskusie. Divadelníci začali spolupracovat’ s nezávislými novinármi a tiež s advokátmi, aby publiku ponúkli pravdivejšiu verziu udalostí. Postupne tak vznikala divadelná fraška, ktorá sa časom neustále aktualizovala. Ako podklad použil Fo 
viaceré autentické materiály. Informácie mu sprostredkúvali prevažne novinári, ktorí sa o prípad zaujímali, no k niektorým dokumentom získal prístup i sám. Ked' zhromaždil potrebný materiál, zostávalo vymysliet’ spôsob, ako ho previest’ do divadelnej podoby. Originálny klúč k riešeniu tohto zadania nakoniec našiel v postave blázna.

Dario Fo vždy kládol v divadle vel'ký dôraz na situáciu, ktorú definoval ako základný kameň, na ktorom autor alebo herec vystavia celú komédiu. V rozhovore s Giuseppinou Manin spomenul, že v hre Náhodná smrt’ anarchistu mu ideu použit takýto typ postavy prinieslo náhodné stretnutie s jedným čudesným mužom: „Donútil ma vypočut’ si jeho príbeh: skončil v psychiatrickej nemocnici vo Forlì kvôli zvláštnej mánii: bola ňou vášeň obliekat’ sa do šiat iných l'udí. (...) kým rozprával, osvietilo ma: klúč pre moju komédiu Náhodná smrt’ anarchistu bol tam, predo mnou. Bol to on. ${ }^{\text {15 }}$

U Foa sa blázon počas výsluchu na policajnej stanici dozvedá, že na stanicu má príst' inšpektor, aby preveril okolnosti jedného záhadného prípadu. Ked' potom náhodou v nestráženom momente skončí v jeho rukách príslušný spis, neodolá pokušeniu prezliect’ sa za očakávaného inšpektora. Inšpekcia prípadu zvláštnej smrti jedného anarchistu sa tak môže začat'.

Anna Barsotti nachádza istý vzt’ah medzi postavou blázna z frašky Náhodná smrt’ anarchistu a klaunmi z Klaunských mystérií. Podl'a jej názoru je histrioman ${ }^{16}$ priamym príbuzným všetkých tých giullari, ktorí rôznymi spôsobmi demaskujú nespravodlivé pomery v spoločnosti. Joseph Farrell definuje blázna z Náhodnej smrti anarchistu dokonca ako Harlekýna v modernom šate. ${ }^{17}$ Podla Foa zohrávala postava blázna v divadle vždy dôležitú úlohu. Na seminároch spracovaných v Manuale minimo dell'attore uvádzal príklad Shakespearovho „fool“, ktorého funkciou je stimulovanie dialektického dialógu v kontrapunkte s inými postavami. Analogicky aj histrioman vo Foovej fraške vystupuje v kontrapunkte s policajtmi: „Všetko toto slúži na zvýraznenie šialeného správania policajtov, ich uvažovania mimo akejkol’vek ,zdravej' logiky prostredníctvom kontrastu. Pretože grotesknost' je úžasným zväčšovacím sklíčkom. Takže ked' sú do toho zapletení politici a policajti, blázon je vždy dobrý žolík, ktorým sa dá hrat'. V ktoromkolvvek období. “18

Na zázname z roku 1987 sa môžeme presvedčit, že komik aj v tejto inscenácii vo vel'kej miere využíval svoje hlasové a pohybové schopnosti. Jeho herectvo ani tentoraz nemožno definovat ako realistické či civilné. Naopak, Fo sa v postave histriomana $\mathrm{v}$ istých chvílach dokonca stával klaunom. Ostatné postavy mu sekundovali svojím štylizovaným prejavom, vd’aka čomu mali niektoré obrazy charakter gagov. Blázon bol však po celý čas jednoznačným protagonistom inscenácie a napriek skutočnosti, že ide o frašku, nepôsobil iba komicky. Na mnohých miestach sa dostával na povrch skôr jeho hnev a rozčarovanie nad situáciou.

Groteskný text často zvádza inscenátorov, obzvlášt mimo Talianska, k jeho nadlahčenej, komediálnej interpretácii. Takéto spracovanie ale nevystihuje ducha historického momentu, ktorý podnietil vznik hry. Forma tragickej frašky, ako dielo

${ }^{15}$ FO, Dario. Il mondo secondo Fo. Conversazione con Giuseppina Manin. Milano : Ugo Guanda Editore, 2008, s. 40 - 41. ISBN 978-88-235-1524-6. Preklad z talianskeho jazyka Michal Denci.

${ }^{16}$ Človek s chorobnou potrebou prezliekat’ sa do šiat iných l'udí, resp. vydávat' sa za iných l'udí.

${ }^{17}$ Pozri FARRELL, Joseph. 2014. Dario e Franca. La biografia della coppia Fo-Rame attraverso la storia italiana, kap. 6, s. 4.

${ }^{18}$ Tamže, s. 41. 
charakterizoval sám Fo, totiž vyplýva z absurdnosti autentických materiálov. Pri koncipovaní diela bolo prvotným zámerom autora stimulovat diskusiu o prípade, ktorý dodnes traumatizuje taliansku spoločnost'. Obnaženie neprávosti prostredníctvom irónie a grotesky patrilo k Foovým typickým divadelným postupom, preto neprekvapuje, že aj zvláštne okolnosti, ktoré sprevádzali Pinelliho výsluch, spracoval práve vo forme frašky. Hru ale nemožno vnímat' ako l’ahkú bezstarostnú komédiu, určenú na večerné odreagovanie sa.

Zrejme najmä nedorozumenia tohto typu zapríčiňovali Foovu nespokojnost' s inscenáciami jeho textov, ktoré pripravili iní tvorcovia. Aj ked’ vyhlasoval, že nemá problém s vol'nou interpretáciou, často s nevôlou prijímal výraznejšie zásahy do svojich hier. Obzvlášt citlivo vnímal úpravy Náhodnej smrti anarchistu: „Niektorí režiséri (Boh ich potrestaj kolesom), ktorých snahou je zrealizovat čistú komédiu, odstránili realistickú indikáciu konfliktu, zveličili komickú hru až do takej miery, že z nej urobili klauniádu, a napokon spravili akúsi surreálnu pochade ${ }^{19}$, kde sa človek ide popukat’ a vychádza z divadla oprostený od akéhokolvek pohoršenia či obt’ažujúcej myšlienky. ${ }^{\text {20 }}$

Niekedy bolo Foovo rozhorčenie vskutku pochopitel’né. Zvlášt po zásahoch politickej cenzúry v niektorých krajinách, kde sa jeho texty menili na nepoznanie. „Ako som povedal, nikdy som nebol zástancom nedotknutelnosti textov. (...) Ale v ZSSR pri zápalistom škrtaní a prepisovaní všetkých politických odkazov to nakoniec dopadlo tak, že nezostalo nič z pôvodného príbehu. Niekto sa v zúfalstve dokonca pokúšal pozliepat to, čo zostalo z dvoch či troch komédií v nádeji, že z toho vyrobí jednu... Výsledok: neuveritel’né guláše. Absurdné je, že tie satirické komédie sme u nás koncipovali, aby sme odsúdili podlost' kapitalizmu. Evidentne sa v očiach sovietskych byrokratov toto odsudzovanie perfektne spájalo aj s ich socialistickým realizmom. ${ }^{21} \mathrm{~V}$ tejto súvislosti spomeňme, že Fo po invázii vojsk Varšavskej zmluvy do Československa v roku 1968 neautorizoval žiadnu inscenáciu svojho diela realizovanú v oficiálnych divadlách tejto neslobodnej krajiny. Možno tak predpokladat', že ak by bol žil na druhej strane železnej opony, pravdepodobne by sa stal disidentom podobne ako Václav Havel, ktorého divadlo oceňoval.

Joseph Farrell upozorňuje aj na tretí typ úprav textu Náhodnej smrti anarchistu (prvé dva typy by sme mohli definovat ako „komická“ a „politická“ cenzúra), ked' pripomína, že niektorí tvorcovia mimo Talianska prispôsobili hru miestnym reáliám a použili ju na mobilizáciu verejnosti proti arogancii moci. Pri takýchto adaptáciách variácia textu azda najmenej narúša jeho integritu, ked’že zachováva pôvodného ducha hry.

\section{Klaunovi stačí málo}

Aj na základe uvedeného možno konštatovat', že Náhodná smrt’ anarchistu patrí vo svete $\mathrm{k}$ najpopulárnejším Foovým textom. Konštatácia o vel'kej oblúbenosti hry mimo Talianska vyznieva takmer paradoxne, ked’že fraška pojednáva o jednej kon-

\footnotetext{
${ }^{19}$ Typ l'ahkej komédie založený na canovacci.

${ }^{20}$ Cit. podla FARRELL, Joseph. Dario e Franca. La biografia della coppia Fo-Rame attraverso la storia italiana, s. 13.

${ }^{21}$ FO, Dario, Il mondo secondo Fo. Conversazione con Giuseppina Manin, s. 35.
} 
krétnej udalosti novodobých talianskych dejín. Môžeme tak predpokladat', že divadelných tvorcov v zahraničí zaujme text popri inom aj originálnou formou a výpovednou silou. $\mathrm{V}$ hre je nepochybne ukrytý vel'ký potenciál, napokon, i samotný Fo dokázal vytvorit údernú inscenáciu s použitím minima prostriedkov. V ním režírovanej inscenácii nič neodpútava divákovu pozornost’ od bláznom proklamovaných faktov. Scéna je zariadená len niekol'kými kusmi kancelárskeho nábytku, dominuje jej okno umiestnené na jednej zo strán. Kostýmy postáv sú civilné a vd’aka niektorým detailom umožňujú pomerne lahkú identifikáciu reálnych aktérov kauzy.

Dario Fo považoval každé divadlo za politické a vnímal ho ako nástroj na stimuláciu reflexie. $Z$ toho dôvodu sa nikdy neusiloval vtiahnut publikum do deja a pôsobit’ naň emocionálne. Naopak, podobne ako Brecht sa snažil dosiahnut', aby si divák zachoval odstup. Len tak sa totiž môže zamysliet’ nad tým, čo komik pertraktuje na javisku. V inscenácii Náhodnej smrti anarchistu dosahuje efekt odcudzenia napríklad i tým, že sa v jednom momente obracia priamo na publikum. Avšak to, čo divákom bráni stotožnit’ sa s postavami, je predovšetkým Foovo herectvo. Aj táto inscenácia je vo vel'kej miere založená na Foovom výnimočnom hereckom prejave. Jeho pohyby a exponovaný hlasový prejav však namiesto výbuchu smiechu vyvolávajú u diváka skôr rozhorčený úškrn. Absurdnost' vyhlásení polície, ktoré zaznievajú ústami inšpektorov, síce vzbudzujú pobavenie, no za daných okolností má smiech vel'mi trpkú príchut'.

Dnes už môžeme povedat', že Dario Fo s hrou dosiahol svoj zámer. Ako konštatuje Joseph Farrell, jeho výklad udalosti sa časom ukázal byt principiálne správnym. Vyšetrovanie Pinelliho smrti napriek tomu nikdy neprinieslo celkom uspokojivé závery.

\section{Politické divadlo nie je len propaganda}

Divadlo v každej dobe odzrkadl’ovalo aktuálnu spoločnost’ a zaznamenávalo jej rôzne záchvevy. $Z$ toho dôvodu Dario Fo nazeral na divadlo ako na prostriedok zobrazenia hodnôt a morálky tej-ktorej spoločnosti $\mathrm{v}$ kontexte politiky doby. Tou najzaujímavejšou zložkou pre neho bolo vždy l'udové divadlo, pretože práve jeho nositelia podávali neidealizovaný obraz o pomeroch, ktoré panovali v jednotlivých spoločenských vrstvách. Ludoví rozprávači a kočovní komedianti sa z tohto dôvodu stali najväčším zdrojom inšpirácie Foovej tvorby. Na komunikáciu problémov súčasného sveta prostredníctvom divadla používal formu, ktorú podla vlastného presvedčenia prebral od stredovekých a renesančných klaunov. Vol'ba tejto formy bola zároveň plne kompatibilná s jeho politickým presvedčením. Fo po celý život s nasadením bojoval za práva utláčaných vrstiev, ku ktorým sa prihováral zrozumitelným jazykom. Na bezprostredné pochopenie jeho diela nie je nutné mimoriadne intelektuálne poznanie: všetky potrebné informácie odovzdal divákovi počas predstavenia. Väčšinou mu už v úvode pred vystúpením ozrejmil svoje motivácie, ktoré ho viedli k výberu konkrétnych vyjadrovacích prostriedkov pri spracovaní vybranej témy.

V mnohých prípadoch však uvedenie do kontextu nebolo nutné: Foovo publikum situáciu zobrazovanú na javisku až príliš dobre poznalo. Neraz to boli práve diváci, ktorí poskytli komikovi nový námet na spracovanie a stali sa tak impulzom pre vznik konkrétnych diel. Dario Fo a Franca Rame pri rozhovoroch pozorne načúvali 
svojim divákom, pochádzajúcim väčšinou z robotníckej triedy, aby spoznali nielen problémy súvisiace $s$ ich spoločenským postavením, ale aby tieto problémy aj verejne komunikovali a názorne predstavili prostredníctvom svojho divadla. Nekompromisnými postojmi dráždili politické autority a museli čelit početným útokom viac či menej významných verejných činitel’ov. Dario Fo bol raz nútený strávit’ noc vo väzení, Franca Rame sa zrejme pre svoje aktivity stala obełou násilného činu. Napriek tomu, že za svoju angažovanost’ museli zaplatit’ mimoriadne vysokú cenu, nikdy nepol'avili a neskrčili sa pred držitel’mi moci. Nestali sa bábkami v rukách iných - naopak, obávaní politici sa v ich divadle premieňali na pajácov, ktorí vyvolávali v divákoch oslobodzujúci smiech.

Dominantnou postavou vo Foovom divadle bol vždy herec. Nie preto, že by si podroboval režiséra či dramatika, ale preto, že sám bol tvorcom v pravom zmysle slova. Texty zaznamenané na papieri možno v jeho prípade vnímat’ skôr ako reminiscencie živých vystúpení než ako ich východisko. Ústredná fáza procesu tvorby sa totiž odohrávala na javisku: Fo v rámci definovanej situácie uplatňoval svoje herecké a pohybové danosti, aby vytvoril materiál, ktorý potom upravoval, aj v nadväznosti na reakcie publika. Svoje vystúpenia vždy adaptoval na aktuálne podmienky. Úvody či scénky prispôsoboval miestnemu publiku a väčšinou v nich reflektoval udalosti, ktoré hýbali spoločnostou. Sila jeho predstavení teda spočívala popri inom aj v jeho schopnosti reagovat' na aktuálny kontext.

V tejto súvislosti neprekvapuje, že filologička Florence Dupont v publikácii Aristoteles alebo upír západného divadla ${ }^{22}$ udel’uje posledné slovo práve Foovi. Tento komik sa dokázal vyhnút nástrahám, ktoré západnému divadlu pripravil Aristoteles, ked' napísal svoju Poetiku. Aristoteles podla Florence Dupont spôsobil (vel'mi zjednodušene povedané), že divadlo v západnom svete bolo zredukované na text, kde najdôležitejšiu úlohu zohrávala kvalita príbehu. Fo viac či menej vedome ignoroval všetky teórie starogréckeho filozofa, vd’aka čomu jeho divadlo napĺn̆alo mnohé atribúty, ktoré podla Dupontovej charakterizovali predstavenia realizované ešte v rámci antických dionýzií. Aj v jeho prípade prichádza text až po predvedení diela a rozhodujúca je najmä vhodnost' tohto diela $\mathrm{v}$ danom priestore a čase.

Foove diela nie sú introspektívne a nezameriavajú sa na emocionalitu človeka. Hrdinovia jeho príbehov nevystupujú ako rozorvané individuality izolované od zvyšku sveta. Dario Fo vo svojich dielach nikdy neskúmal psychológiu postáv, neponáral sa do ich vnútorného sveta. neanalyzoval ich duševné poryvy. Jeho divadlo neponúka pohl'ad do útrob duše, ale do útrob l'udskej spoločnosti.

Urobili by sme vel'kú chybu, ak by sme sa snažili hodnotit' Foove texty na základe literárnych či nebodaj aristotelovských kritérií. Takejto chyby sa evidentne vyvarovali členovia Švédskej akadémie, ked’ Foovi udelili v roku 1997 Nobelovu cenu za literatúru. Dôvodom jeho ocenenia určite nebola slabá konkurencia: na Nobelovu cenu v tom istom roku ašpiroval napríklad taký velikán, akým bol Mario Luzi, florentský poet, ktorého básne visia zarámované na stenách talianskej národnej knižnice. Neortodoxná vol'ba členov Švédskej akadémie vyvolala protichodné reakcie talianskej kultúrnej a politickej scény. Niektorí Foovi nadšene gratulovali, iní sa pohoršovali

${ }^{22}$ DUPONT, Florence. Aristoteles alebo upír západného divadla. Z francúzskeho originálu Aristote ou le vampire du théâtre occidental (2007) preložila Elena Flašková. Bratislava : Divadelný ústav, 2016. ISBN 97880-8190-013-6. 
a nesúhlasne krútili hlavou. Neverili, že by král’ov literatúry mohol predbehnút ludový šašo.

\title{
DARIO FO: THE BIRTH OF A CLOWN
}

\section{Michal DENCI}

The study maps the work of an Italian performer and Nobel Prize winner for literature Dario Fo. Its base is a brief recap of the most significant episodes of Fo's early career. The biographical part includes the comic's first interactions with professional theatre, his experience with film, television and the emergence of his first theatre associations. There are also some basic ideas outlined, which inspired the form and content of Fo's theatre. Dario Fo's dramatic work is analyzed through two titles that represent the main lines of his productions. The first line consists of a clown comedy (genre called giullarata) in which Mistero Buffo is the most important. The predominantly monologic forms, inspired by folk theatre, are mainly characterized by the grammelot language and the emphasis is placed on the performance and voice skills of the performer. In the second line, the attention of the author of the study focuses on grotesque comedies, represented by the farce Morte accidentale di un anarchico. The play inspired by an actual event has responded to the current social context and stimulated social debate. At the same time, the genesis analysis of both works reveals Dario Fo's creative processes.

Vznikol v rámci doktorandského štúdia na Divadelnej fakulte Vysokej školy múzických umení v Bratislave, školitel'ka Soňa Šimková.

\author{
Michal Denci \\ Divadelná fakulta \\ Vysoká škola múzických umení \\ Zochova 1 \\ 81301 Bratislava \\ e-mail: michal.denci@gmail.com
}

